\title{
MODELLING OF INTERNAL COMBUSTION ENGINES' EMISSION THROUGH THE USE OF TRAFFIC FLOW MATHEMATICAL MODELS
}

\author{
Raimundas Junevičius ${ }^{1}$, Marijonas Bogdevičius ${ }^{2}$, Ádám Török ${ }^{3}$ \\ ${ }^{1,2}$ Dept of Transport Technological Equipment, Vilnius Gediminas Technical University, \\ Plytines g. 27, LT-10105 Vilnius, Lithuania \\ ${ }^{3}$ Dept of Transport Economics, Budapest University of Technology and Economics, \\ Bertalan Lajos str. 2, H-1111 Budapest, Hungary \\ E-mails: ${ }^{1}$ raimundas.junevicius@vgtu.lt (corresponding author); \\ ${ }^{2}$ marijonas.bogdevicius@vgtu.lt; ${ }^{3}$ atorok@kgazd.bme.hu
}

Received 16 July 2011; accepted 5 September 2011

\begin{abstract}
Road traffic flows on a straight road segment are modelled in this article. The mathematical model of traffic flows has been constructed by using the method of lumped parameters. $\mathrm{CO}_{2}, \mathrm{CO}, \mathrm{CH}, \mathrm{NO}_{\mathrm{x}}, \mathrm{PM}$ regression equations of internal combustion engines' (ICE) emission has been developed. The accuracy of regression equations is $0.98 \div 0.99$. The article presents assumptions for constructing the mathematical model, description of the mathematical model and gives simulation results. Traffic flow parameters, such as traffic flow concentration and traffic flow speed are presented as modelling results. ICE emission depending on the concentration and traffic flow speed are presented as well.
\end{abstract}

Keywords: traffic flow, mathematical modelling, internal combustion engine, emission, numerical simulation, fuel consumption.

\section{Introduction}

Road transport is one of the main inland transport modes providing house to house services for the people all over the world. Each inland territory is criss-crossed by interurban road and street network. Vehicle flows carry people, distribute, industrial freight and work equipment on these network elements. Majority of these road vehicles are driven by internal combustion engines; therefore besides practical use they also create a lot of problems, such as air pollution with combustion products and particulate metter, noise, vibration, utilization of used oil and other materials, recycling of cars and their parts. Cars consume a lot of energy; therefore when solving problems caused by them a lot of engineers and scientists put a lot of efforts to solve a wide range of problems starting from vehicle manufacturing to their utilization.

A lot of burning problems arise when cars are used and here the main problems to be solved by both engineers and scientists are pollution reduction and energy saving. When saving energy, cars become more environment-friendly. Various problems caused by vehicles are discussed in the article written by Makaras et al. (2011). The authors discuss vehicle dynamics in the flow, fuel consumption, the impact of environment on the dynamics of cars, touch upon the driver's model and various driving styles. Wang et al. (2008) presented various meth- ods of fuel consumption and engines' emission measuring as well as coefficients of efficiency. Tanczos and Torok (2007) investigated climate fluctuation changes and energy consumption in Hungary. The article presents the dynamics of climate and $\mathrm{CO}_{2}$ change as well as energy consumption in the Republic of Hungary. $\mathrm{CO}_{2}$ emissions are presented as well: $1 \mathrm{~mol}$ of diesel (198 g) yields $14 \mathrm{~mol}$ or $616 \mathrm{~g} \mathrm{CO}_{2}$ and $1 \mathrm{~mol}$ (114 g) of petrol yields $8 \mathrm{~mol}$ or $352 \mathrm{~g} \mathrm{CO}_{2}$. Janulevičius et al. (2010) presented the methodology of determining energy consumption taking into account engine's capacity and specific fuel consumption. Wu and Liu (2011) in their article presented the methodology of calculating fuel consumption by taking into account such criteria as aerodynamic and rolling resistance. Fuel consumption model was constructed and based on the neural network theory. Smit et al. (2008) presented and generalized three emission models, where the impact of congestions on motor vehicles' emission is evaluated differently and present indicators to identify transport congestions. The article also presents congestion identification models. Jović and Đorić (2010) used programming package PTV Visio to model traffic flows on the urban street network and based on that present vehicle emissions. Jakimavičius and Burinskienè (2010) investigated vehicle flow optimization methods and their application possibilities when informing traffic us- 
ers about the situation in the city, and in their article (Jakimavičius, Burinskiene 2009a, 2009b) presented the rating system of the Vilnius city residential areas by using expert methods and pointed out the residential areas with the highest traffic volumes of the city. Kliukas et al. (2008) investigated the impact of vibrations caused by vehicles on buildings with the aim to preserve cultural values in the city of Vilnius. Frequencies 1.3 and $10.8 \mathrm{~Hz}$ are presented as dangerous. Žiliūte et al. (2010) investigated traffic flows and presented the data obtained on high intensity streets of Vilnius city. Sivilevičius (2011) investigates the interaction of transport system elements by taking into account traffic flow elements.

This article gives an example of applying mathematical models of traffic flows to simulate internal combustion engine (ICE) emission. The article does not investigate combustion reactions of ICE; however, it uses ICE emission dependences on the vehicle's movement speed, which are developed by using the values of emissions.

\section{Assumptions of Constructing a Road Segment}

When describing traffic flows, a traffic lane is used as a keyword. An assumption is taken that cars cannot drive on an opposite traffic lane; therefore, the road is split into separate traffic lanes and two-way roads are described in the mathematical model as a separate oneway road with one or several traffic lanes. In this model a traffic lane segment is taken as a finite-length line, which is divided into equal length segments the length of which is $L$ (Fig. 1). The parameters of a road segment (traffic flow speed, traffic flow concentration or traffic flow intensity) accumulate at the end points. The point which connects two adjacent segments has a point common to both segments. The first and the last points of a traffic lane under investigation are data entry points at boundary conditions. Minimal and maximal values of traffic flow parameters for each road segment are set separately and may be different. Minimal values of traffic flow speed and concentration are usually equal to zero. Maximal possible value of speed is based on observations. Maximal permitted traffic flow concentration value may be calculated according to the following formula:

$$
k=\frac{n_{v e h}}{L_{i, i+1}},
$$

where: $n_{\text {veh }}$ - a number of vehicles in segment (units), $L_{i, i+1}$ - a road segment length (m).

Let us suppose that a road segment cannot be overfilled. If a number of vehicles on a road segment reaches

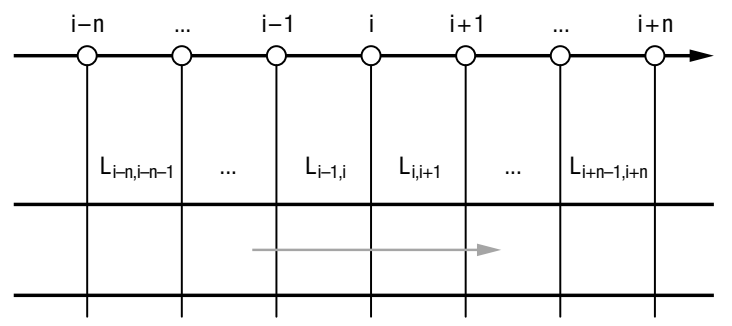

Fig. 1. Transport flow model on a straight segment of a traffic lane an upper concentration limit, more vehicles cannot enter this road segment. If a road segment is full, the value of vehicles' flow remains the same, increases or slightly decreases, but is insufficient and the road segment ahead remains overfilled, vehicles start accumulating on the road segment subsequent to the full road segment.

Vehicle flow speed is limited as well. Each road segment has its own speed limit which can differ.

If the road has several one-way traffic lanes, an assumption that there is one traffic lane, the concentration parameters of which are proportionally increased, is taken in the simulation. This assumption enables to connect several one-way traffic lanes into one and the model becomes simpler because the migration of vehicles from one traffic lane to another does not have to be taken into account.

Traffic lane segments that are split in the model are numbered $L_{i-1, i}, L_{i+1, i}$ when $i=1 \ldots n, i$ - road point number. (Fig. 2). Points at the ends of this segment are merged with the ends of adjacent elements. The first point of an element is equal to the last point of the preceding element, and the last point of an element is equal to the first point of the subsequent element. Boundary conditions of the task are entered on boundary elements, the first point of the first element and the last point of the last road element. a)

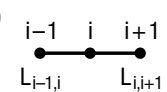

b)

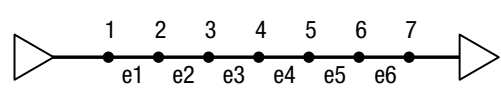

Fig. 2. Description of elements of a straight road: a - two elements $L_{i-1, i}$ and $L_{i+1, i}$, are connected at point $i$;

b - a straight road segment drawn from several road segments connected at points $1 \div 7$

Such points of boundary conditions (Fig. 2) are 1 and 7. At these points during the whole modelling time the input and output system information is known. Therefore, the value of the flow, which may be constant or change according to the law known in advance during the whole modelling time, is frequently entered into the system.

\section{The Mathematical Model for Description of Traffic Flows and Internal Combustion Engines' (ICE) Emission}

\subsection{Mathematical Model of Traffic Flows}

Equations describing traffic flows and the explanation of equation members are presented in the paper of Junevičius, Bogdevičius (2009). Hereinafter mathematical expressions are presented.

Mathematical expressions of traffic flow parameters are described by the following formulae:

$$
\begin{aligned}
& \dot{k}_{i}=p_{\text {in }, i}(t) \cdot r_{k, i n ., i} \cdot\left(1-\frac{k_{i}(t)}{k_{\max , i}}\right) \cdot\left(\frac{q_{i-1}\left(t-\tau_{i-1}\right)}{q_{\max , i-1}}\right) \cdot k_{i}(t)- \\
& p_{\text {out }, i}(t) \cdot r_{k, \text { out }, i} \cdot\left(1-\frac{k_{i+1}(t)}{k_{\max , i+1}}\right) \cdot\left(\frac{q_{i}(t)}{q_{\max , i}}\right) \cdot k_{i}(t) ;
\end{aligned}
$$




$$
\begin{aligned}
& \dot{v}_{i}=p_{\text {in }, i}(t) \cdot r_{v, i n ., i} \cdot\left(\frac{v_{i-1}\left(t-\tau_{i-1, i}\right)}{L_{i-1, i}}\right) \cdot\left(1-\frac{k_{i}(t)}{k_{\max , i}}\right) \cdot v_{i}(t)+ \\
& f_{i}\left(k_{i+1, i}\right)-p_{\text {out }, i}(t) \cdot r_{v, \text { out }} \cdot\left(\frac{1}{2} \frac{v_{i}(t)+v_{i+1}(t)}{L_{i+1, i}}\right) \times \\
& \left(1-\frac{k_{i+1}(t)}{k_{\max , i+1}}\right)^{m_{1}} \cdot v_{i}(t)-\left(\frac{v_{i}(t)}{v_{\text {max }, i}}\right) \cdot e^{\left[\gamma_{3}\left(\frac{k_{i}(t)}{k_{\max , i}}\right)^{m_{2}}\right] \cdot\left(\frac{v_{i}(t)}{v_{\text {max }, i}}\right),}
\end{aligned}
$$

where (for simplicity parameters are described without indexes $i-1, i, i+1): k(t), v(t)$ - sought traffic flow parameters: traffic flow concentration and speed; $k_{\max }-$ maximum possible flow concentration on a road segment $(\mathrm{veh} / \mathrm{m}) ; v_{\max }-$ maximum possible traffic flow speed on the element $(\mathrm{m} / \mathrm{s}) ; L$ - discrete road segment length $(\mathrm{m})$; $\tau$ - time interval necessary for a traffic flow to cover a road segment, the length of which is equal to $L(\mathrm{~s})$; $m_{1}, m_{2}, \gamma$ - constants; $q$ - traffic flow intensity (veh/s); $q_{\max }-$ maximum possible intensity of the flow (veh/s); $r_{k, \text { in }}, r_{k, \text { out }}$ - values of function introducing the correction for flow concentration change expression; $r_{v, i n}$, $r_{v, \text { out }}$ - function values introducing correction for flow speed change expression (functions $r_{k, \text { in }}, r_{k, \text { out }} r_{v, \text { in }}, r_{v, \text { out }}$ depend on the concentration and speed values and these functions may have different values when the flow enters and leaves the element); $p_{\text {in }}(t), p_{\text {out }}(t)$ - probability of the flow entering the segment ahead (function $p_{\text {in }}(t)$, $p_{\text {out }}(t)$ values change in the course of time depending on the concentration and flow speed values' change or may be introduced as handling functions; $f_{\mathrm{i}}\left(k_{\mathrm{i}+1, \mathrm{i}}\right)$ the function which depends on the unknown parameter $k$ (this function describes the condition of the road segment element preceding road point ' $i$, i.e. it shows how intensively loaded this traffic lane segment is):

$$
\begin{aligned}
& f_{i}=\left\{\begin{array}{c}
e_{2}\left(1-\frac{\varepsilon_{i+1}}{\varepsilon_{i}}\right) \cdot \varepsilon_{i} \cdot \operatorname{sign}\left(p_{\text {out }, i}(t)\right) \cdot \operatorname{sign}\left(1-\frac{\varepsilon_{i+1}}{\varepsilon_{i}}\right), \text { if } \varepsilon_{i}>\varepsilon_{i+1} \text { and } \varepsilon_{i}>0 ; \\
0, \text { in other case; }
\end{array}\right. \\
& \varepsilon_{i}=\frac{k_{i}}{k_{\text {max }, i}} .
\end{aligned}
$$

The functions obtained when flow parameters change have the following advantages:

- both functions of parameters change in the course of time and influence each other.

- specified empirical functions $r_{k, i n}, r_{k, o u t}, r_{v, i n}$, $r_{v, \text { out }}$, which reduce sharp leaps of unknown parameters' values are introduced.

- functions allow the concentration value to obtain 0 value and functions do not approximate to $\infty$.

Members of the equation system (2) and (3) correct the sought parameters of the flow speed and concentration.

$$
\text { Equation (2) member } 1-\frac{k_{i}(t)}{k_{\max , i}} \text { describes traf- }
$$

fic flow concentration change speed at point ' $i$ '. Equa- tion (2) member $1-\frac{k_{i+1}(t)}{k_{\max , i+1}}$ describes the speed of traffic flow concentration change at point ' $i+1$ ', and when traffic flow concentration on a traffic lane segment ahead of point ' $i$ ', in the direction of traffic flow movement, the value of this member approximates to zero (element's loading approximates to the maximum possible concentration on the segment). Therefore, a restriction which does not allow to overfill a traffic lane segment element is established. Moreover, when traffic flow concentration at points ' $i$ ' and ' $i+1$ ' approximates to value $k_{\max }$, concentration change speed decreases.

$$
\text { Equation (2) member } \frac{q_{i-1}\left(t-\tau_{i-1}\right)}{q_{\max , i-1}} \text { describes }
$$

the condition of traffic flow on the segment preceding point ' $i$ ' in the direction of traffic flow movement. This member describes the flow concentration increase or decrease at point ' $i$ ' depending on the flow intensity on a traffic lane segment which precedes point ' $i$. Time interval $\tau_{i-1}$ during which the flow travels from one point to another is taken into account as well. This delay enables to describe the movement of the flow from one point to another more accurately in cases when the distance between points is relatively big, and the flow movement speed is relatively small. Such situation arises when a traffic lane is divided into long segments, and the flow movement speed is close to $0 \mathrm{~m} / \mathrm{s}$ but is not equal to 0 . The longer the distance between points and the smaller the flow movement speed on the segment are, the longer the delay time is.

$$
\text { Equation (3) member }\left(\frac{v_{i-1}\left(t-\tau_{i-1, i}\right)}{L_{i-1, i}}\right) \cdot v_{i}(t) \text { de- }
$$

scribes traffic flow acceleration at point ' $i-1$ ' and its impact on the flow speed at point ' $i$ '; meanwhile member $\left(\frac{1}{2} \frac{v_{i}(t)+v_{i+1}(t)}{L_{i+1, i}}\right) \cdot v_{i}(t)$ describes average traffic flow acceleration between points ' $i$ ' and ' $i+1$ '. The latter member also takes into account the flow condition at the point subsequent to point ' $i$ ' in the direction of the flow movement. If traffic flow speed ' $i+1$ ' decreases, the speed at point ' $i$ ' decreases as well, and vice versus if the speed at point ' $i+1$ ' increases, the speed at point ' $i$ ' increases as well.

Equation (3) member $\left(1-\frac{k_{i+1}(t)}{k_{\max , i+1}}\right)^{m_{1}}$ describes traffic flow acceleration change between points ' $i$ ' and ' $i+1$ '. If vehicle concentration on the preceding traffic lane segment is low, the value of the coefficient approximates to 1 ; when concentration is high, it approximates to 0 . Therefore, when concentration on the preceding road segment increases, vehicle flow speed on road sec-

tion ' $i$ ' decreases.
Equation (3) member $1-\frac{k_{i}(t)}{k_{\max , i}}$ does not allow the system to overfill at point ' $i$ '. When flow concentration value approximates to $k_{\max }$, the value of the above-men- 
tioned member approximates to 0. Meanwhile, member $\left(\frac{v_{i}(t)}{v_{\max , i}}\right) \cdot e^{\left(\gamma_{3}\left(\frac{k_{i}(t)}{k_{\max , i}}\right)^{m_{2}}\right) \cdot\left(\frac{v_{i}(t)}{v_{\max , i}}\right)}$ takes into account the number of vehicles at point ' $i$ ' and directly impacts on the concentration value at point ' $i$.

The number of vehicles on a traffic lane segment is calculated according to the following formula:

$$
N_{e}=\int_{x_{i}}^{x_{j}} k(x) d x,
$$

where: $x_{i}, x_{j}$ - boundary points of a traffic lane segment, $k(x)$ - traffic flow concentration on a traffic lane segment.

Change in the number of vehicles on a traffic lane segment is described as follows:

$$
N_{i}(t)=N_{i}(t)+\int_{t_{i}}^{\Delta t+t_{i}} q_{i}(t) d t,
$$

where: $q_{i}(t)$ - vehicle flow rate on traffic lane segment ' $i$.

In the text below an example of applying the mathematical model of lumped parameters of traffic flows is presented.

\subsection{Equations for Description of ICE emissions}

Modelling of automobile combustion products is rather complicated. The authors Mansha et al. (2010) and Descombes et al. (2003) investigate processes occurring in the internal combustion engine chamber in detail. The articles present programming packages used to simulate combustion processes and one can find out that the simulation of combustion processes is complicated and have a lot of random parameters which may influence on the simulation result. The most commonly used engines were generalised and their emissions were measured by autors (KTI - Institite for Trasnport Sciences) of document ÚTMUTATÓ... (2006). The presented article contains these experimental data used to describe engines' emissions, which are presented in Table 1.

According to the statistical data presented by SE 'Regitra' (http://www.regitra.lt), the number of motor vehicles registered in Lithuania are presented in Table 2. Lithuanian (Lietuvoje įregistruotų... 2011) and Hungarian (Markovits-Somogyi, Torok 2010) vehicle fleetcare is very similar so for the modelling is used Lithuanian vehicle fleet.

The data presented in Table 2 show that M1 and N1 category vehicles, according to the data of 1 January 2011 (Lietuvoje ịregistruotu... 2011), make up 95.11\% of registered vehicles; therefore, vehicular ICE emissions measured at different vehicle movement speeds are used for mathematical modelling (Table 1).

The dimensions of the values in Table 1 are measured in $\mathrm{g} / \mathrm{h}$ and in $\mathrm{g} / \mathrm{km}$. The values from Table 1 are converted from $\mathrm{g} / \mathrm{h}$ to $\mathrm{g} / \mathrm{s}$ and are used to build the regression equations Figs 3-7. These functions describing ICE emissions, which depend on one variable parameter, i.e. speed. Programming package Matlab was used to write functions. The method of writing each function is different because the curve which complies with the most measured parameters was sought for.

Functions describing ICE emissions, coefficients' values, written functions and graphical expressions of the measured values are presented in Figs 3-7. The compliance of regression functions with the measured data is $98-99 \%$ for all presented functions.

These functions are included in the mathematical model of the road traffic flow and may be used when forecasting or investigating road pollution dynamics.

\begin{tabular}{|c|c|c|c|c|c|c|c|c|c|c|c|}
\hline \multirow{3}{*}{$\begin{array}{l}\text { Speed, } \\
\mathrm{km} / \mathrm{h}\end{array}$} & \multirow{3}{*}{$\begin{array}{l}\text { Emission } \\
\text { measuring } \\
\text { units }\end{array}$} & \multicolumn{5}{|c|}{ Passenger Cars } & \multicolumn{5}{|c|}{ Heavy Goods Vehicles } \\
\hline & & \multicolumn{10}{|c|}{ Emission factors for 2010 - forecast by the Hungarian dataset (2005) } \\
\hline & & $\mathrm{CO}$ & $\mathrm{CH}(\mathrm{FID})$ & $\mathrm{NO}_{\mathrm{x}}$ & $\mathrm{PM}$ & $\mathrm{CO}_{2}$ & $\mathrm{CO}$ & $\mathrm{CH}(\mathrm{FID})$ & $\mathrm{NO}_{\mathrm{x}}$ & $\mathrm{PM}$ & $\mathrm{CO}_{2}$ \\
\hline 0 & $\mathrm{~g} / \mathrm{h}$ & 69.5 & 4.975 & 2.11 & 0.357 & 1554 & 61.0 & 7.80 & 21.35 & 1.98 & 6631.5 \\
\hline 5 & $\mathrm{~g} / \mathrm{km}$ & 13.90 & 0.995 & 0.422 & 0.0714 & 310.8 & 12.20 & 1.560 & 4.27 & 0.396 & 1326.3 \\
\hline 10 & $\mathrm{~g} / \mathrm{km}$ & 11.00 & 0.900 & 0.416 & 0.0597 & 262.7 & 10.20 & 0.611 & 3.84 & 0.321 & 1040.0 \\
\hline 20 & $\mathrm{~g} / \mathrm{km}$ & 7.12 & 0.714 & 0.394 & 0.0439 & 203.0 & 7.46 & 0.423 & 3.13 & 0.250 & 808.7 \\
\hline 30 & $\mathrm{~g} / \mathrm{km}$ & 5.33 & 0.590 & 0.405 & 0.0351 & 171.7 & 5.86 & 0.285 & 2.83 & 0.221 & 716.5 \\
\hline 40 & $\mathrm{~g} / \mathrm{km}$ & 3.97 & 0.435 & 0.411 & 0.0292 & 154.9 & 4.96 & 0.209 & 2.76 & 0.206 & 658.3 \\
\hline 50 & $\mathrm{~g} / \mathrm{km}$ & 3.14 & 0.418 & 0.427 & 0.0255 & 148.0 & 4.18 & 0.166 & 2.73 & 0.195 & 635.6 \\
\hline 60 & $\mathrm{~g} / \mathrm{km}$ & 2.37 & 0.416 & 0.486 & 0.0247 & 147.4 & 3.70 & 0.140 & 2.86 & 0.194 & 633.1 \\
\hline 70 & $\mathrm{~g} / \mathrm{km}$ & 1.72 & 0.392 & 0.556 & 0.0249 & 151.0 & 3.18 & 0.125 & 3.13 & 0.191 & 660.2 \\
\hline 80 & $\mathrm{~g} / \mathrm{km}$ & 1.52 & 0.379 & 0.623 & 0.0263 & 156.5 & 2.78 & 0.124 & 3.55 & 0.201 & 719.4 \\
\hline 90 & $\mathrm{~g} / \mathrm{km}$ & 1.76 & 0.418 & 0.668 & 0.0286 & 165.6 & 3.17 & 0.126 & 4.13 & 0.227 & 822.6 \\
\hline 100 & $\mathrm{~g} / \mathrm{km}$ & 2.07 & 0.433 & 0.724 & 0.0316 & 178.4 & 3.96 & 0.131 & 5.06 & 0.256 & 990.4 \\
\hline 110 & $\mathrm{~g} / \mathrm{km}$ & 2.72 & 0.442 & 0.782 & 0.0345 & 194.3 & - & - & - & - & - \\
\hline
\end{tabular}

Table 1. Automobile emissions dependences on vehicles' movement speed (ÚTMUTATÓ... 2006) 
Table 2. The number of road vehicles registered in Lithuania (data of 1 January 2011)

\begin{tabular}{|c|c|c|c|c|c|c|}
\hline $\begin{array}{l}\text { M1 passenger } \\
\text { cars (units) }\end{array}$ & $\begin{array}{l}\text { N1 heavy goods } \\
\text { vehicles up to } \\
3.5 \mathrm{t} \text { (units) }\end{array}$ & $\begin{array}{l}\text { M2 A buses up } \\
\text { to } 5 \mathrm{t} \text { (units) }\end{array}$ & $\begin{array}{l}\mathrm{N} 2 \text { heavy goods } \\
\text { vehicles over } 3.5 \mathrm{t} \text { up } \\
\text { to } 12 \mathrm{t} \text { (units) }\end{array}$ & $\begin{array}{c}\text { M3 buses } \\
\text { over } 5 \text { t (units) }\end{array}$ & $\begin{array}{l}\text { N3 heavy goods } \\
\text { vehicles over } 12 \mathrm{t} \\
\text { (units) }\end{array}$ & $\begin{array}{c}\text { Total } \\
\text { (units) }\end{array}$ \\
\hline 1734047 & 95930 & 7690 & 33628 & 7054 & 45651 & \\
\hline \multicolumn{2}{|c|}{$\mathrm{M} 1+\mathrm{N} 1=1829977$} & \multicolumn{2}{|c|}{$\mathrm{M} 2+\mathrm{N} 2=41318$} & \multicolumn{2}{|c|}{$\mathrm{M} 3+\mathrm{N} 3=52705$} & \\
\hline \multicolumn{2}{|c|}{$95.11 \%$} & \multicolumn{2}{|c|}{$2.15 \%$} & \multicolumn{2}{|c|}{$2.74 \%$} & $100 \%$ \\
\hline
\end{tabular}

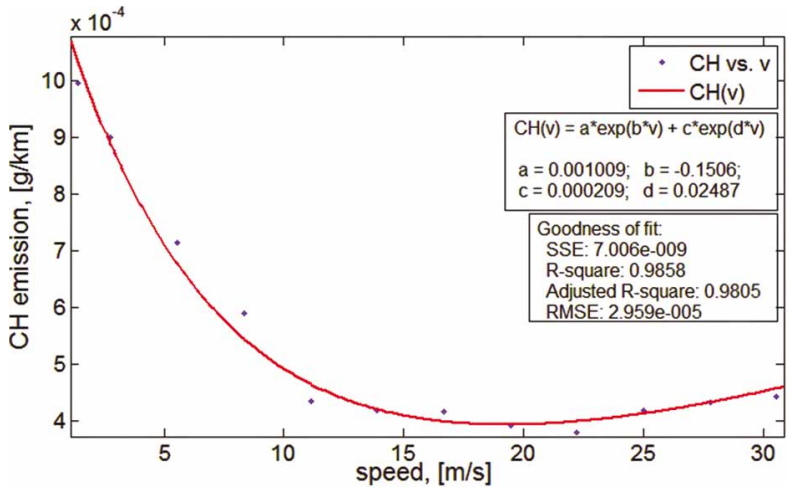

Fig. 3. Dependence of internal combustion engine $\mathrm{CH}$ emission on speed

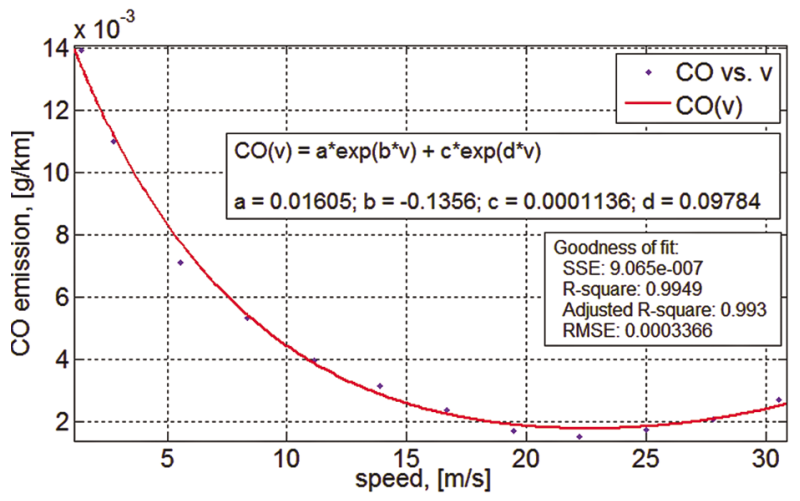

Fig. 4. Dependence of internal combustion engine $\mathrm{CO}$ emission on speed

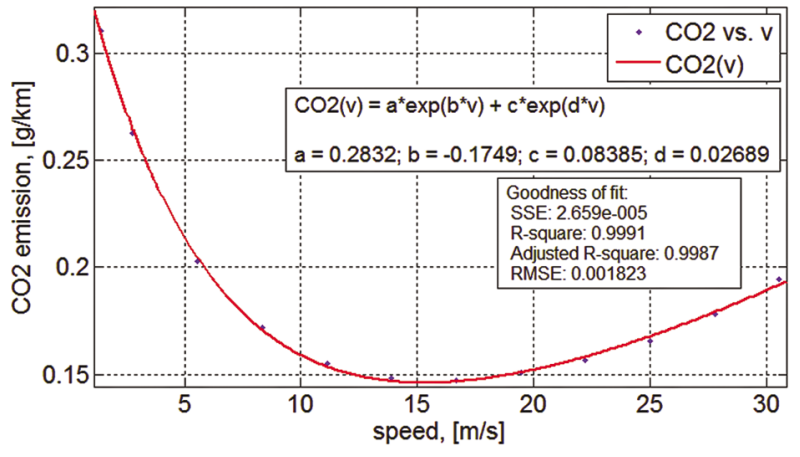

Fig. 5. Dependence of internal combustion engine $\mathrm{CO}_{2}$ emission on speed

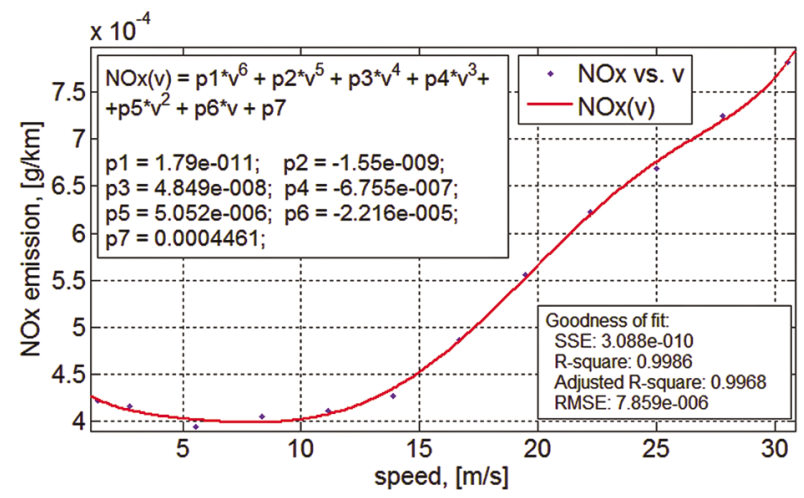

Fig. 6. Dependence of internal combustion engine $\mathrm{NO}_{\mathrm{x}}$ emission on speed

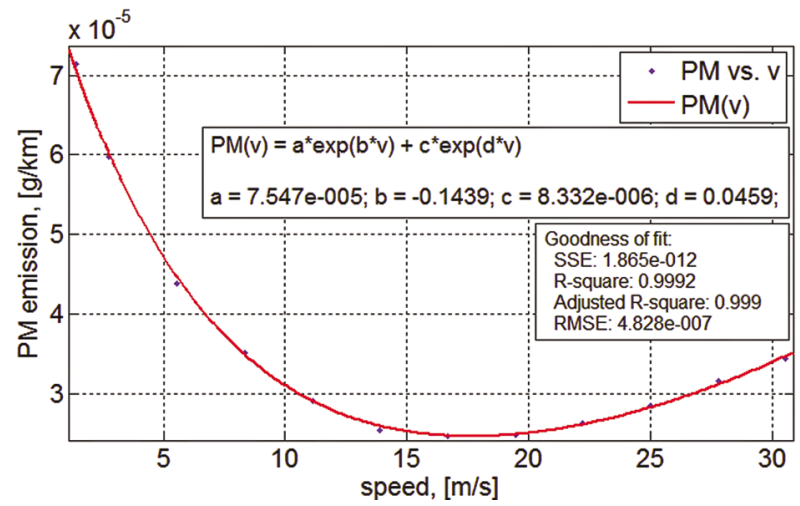

Fig. 7. Dependence of internal combustion engine PM emission on speed

Regression equation and the function of the $\mathrm{CO}_{2}$ emissions are shown in Fig. 5. Red line is negative when speed is close to $0 \mathrm{~m} / \mathrm{s}$. There is some limitation used to avoid inaccuracies in modelling. The speed value could variate from $0.1 \mathrm{~m} / \mathrm{s}$ to $v_{\max }$. Then the lowest $\mathrm{CO}_{2}$ emission quantity is not less than $0.06 \mathrm{~g} / \mathrm{m}$. The emissions are calculated in two different cases. When the speed is less or equal to $0.1 \mathrm{~m} / \mathrm{s}$ then emissions values from Table 1 are taken in $\mathrm{g} / \mathrm{h}$. These emission values are recalculated from Table 1 data when the speed is equalt to $5 \mathrm{~km} / \mathrm{h}$. When the speed is less or equal to $0.1 \mathrm{~m} / \mathrm{s}$ then emissions values (see Table 1) are taken in $\mathrm{g} / \mathrm{h}$. Examples of such modelling are presented in the next chapter. 


\section{Modelling Examples}

The mathematical model is constructed based on the assumptions presented in Chapter 2. A straight $100 \mathrm{~m}$ long road section, at the ends of which boundary conditions of the task are introduced, is taken for modelling. A section of the simulated road is divided into 6 segments. Boundary conditions of the task are introduced at points 1 and 7.

Two tasks are solved. According to the conditions of task 1 , the road is filled in the beginning of the simulation, and boundary conditions are as follows: $v_{1}=$ $5.0 \mathrm{~m} / \mathrm{s} ; v_{7}=0.1 \mathrm{~m} / \mathrm{s} ; k_{1}=0.18 \mathrm{veh} / \mathrm{m} ; k_{7}=0.18 \mathrm{veh} / \mathrm{m}$ in the initial moment $k=0.01 \mathrm{veh} / \mathrm{m}$ and $v=1.0 \mathrm{~m} / \mathrm{s}$ at all points.

Modelling results are presented in Figs 8-14.

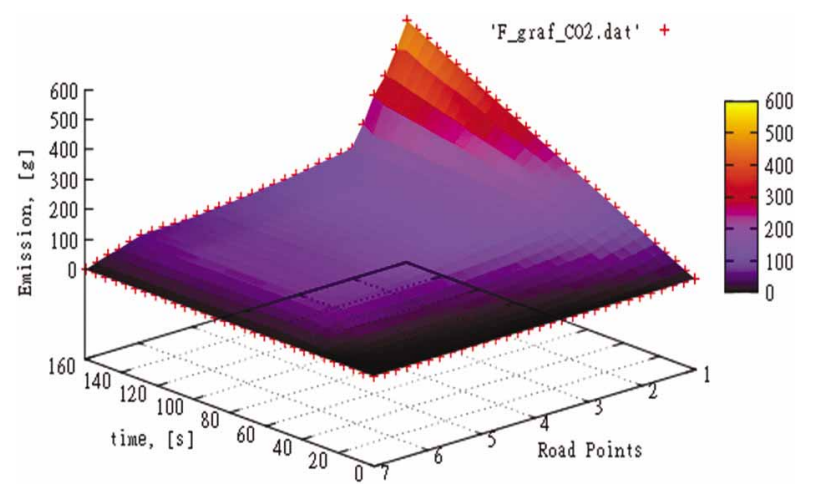

Fig. 8. Dependence of internal combustion engine $\mathrm{CO}_{2}$ emission on time at road points

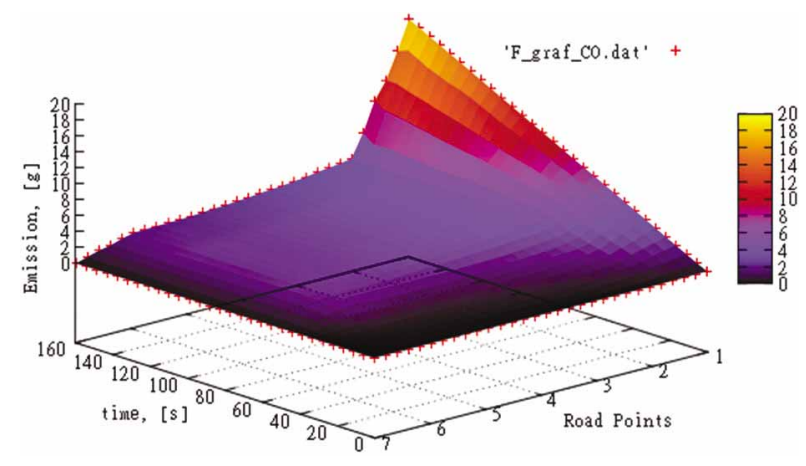

Fig. 9. Dependence of internal combustion engine $\mathrm{CO}$ emission on time at road points

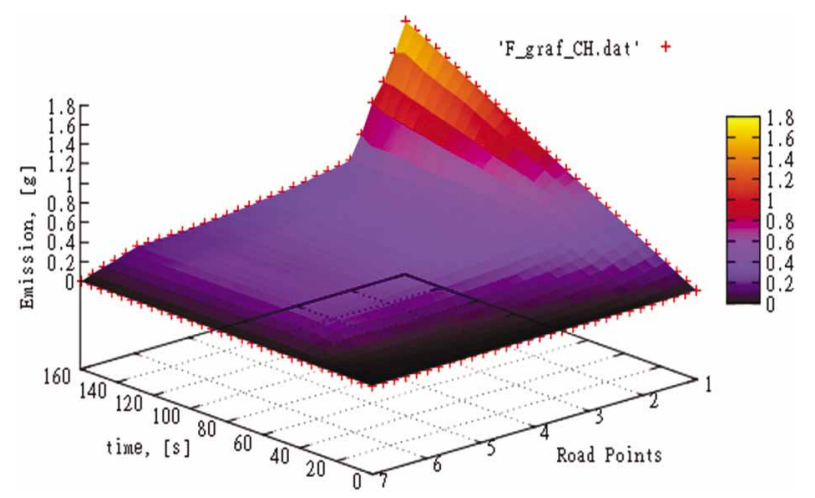

Fig. 10. Dependence of internal combustion engine $\mathrm{CH}$ emission on time at road points

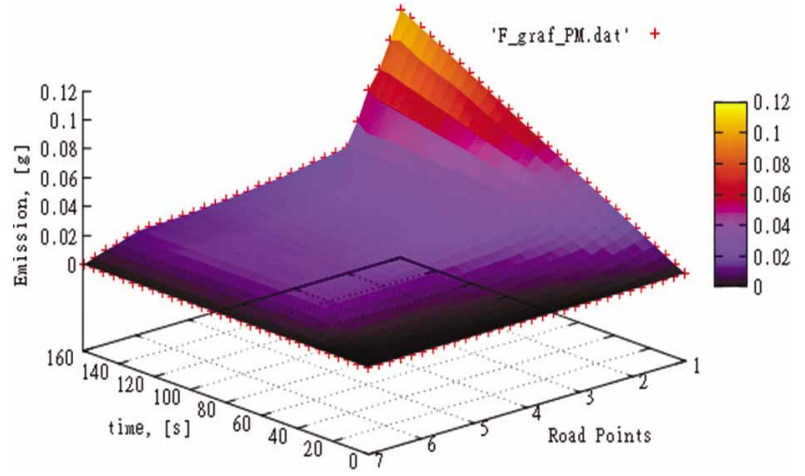

Fig. 11. Dependence of internal combustion engine $\mathrm{Pm}$ emission on time at road points

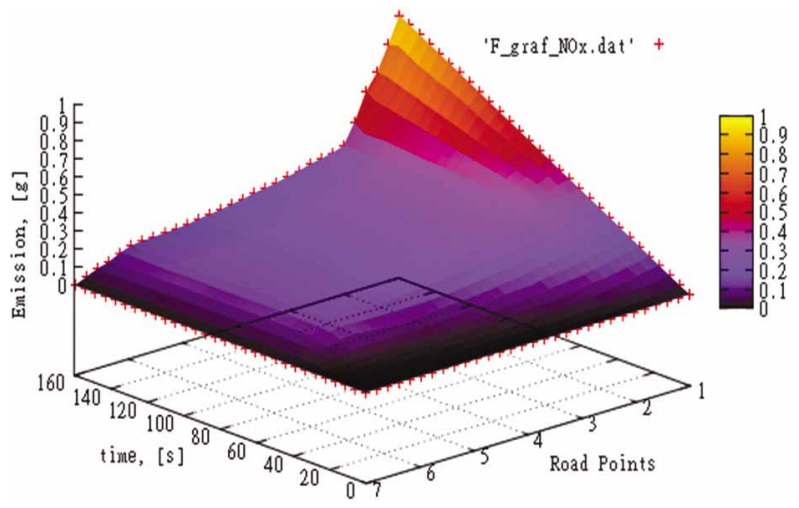

Fig. 12. Dependence of internal combustion engine $\mathrm{NO}_{\mathrm{x}}$ emission on time at road points

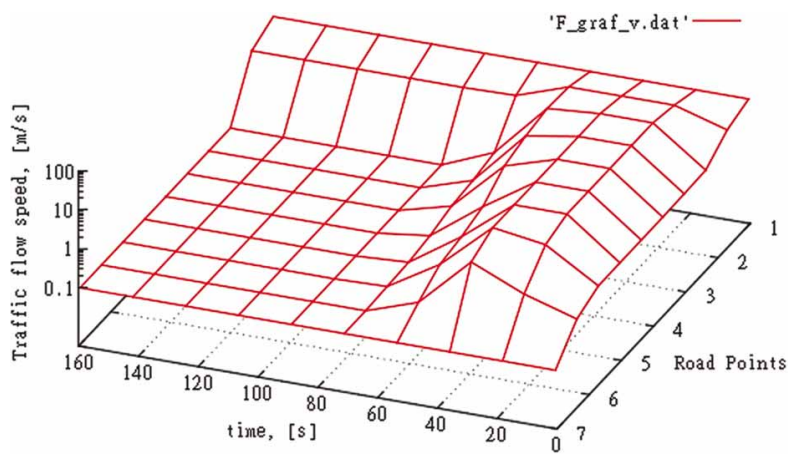

Fig. 13. Dependence of vehicles' flow speed on time at road points

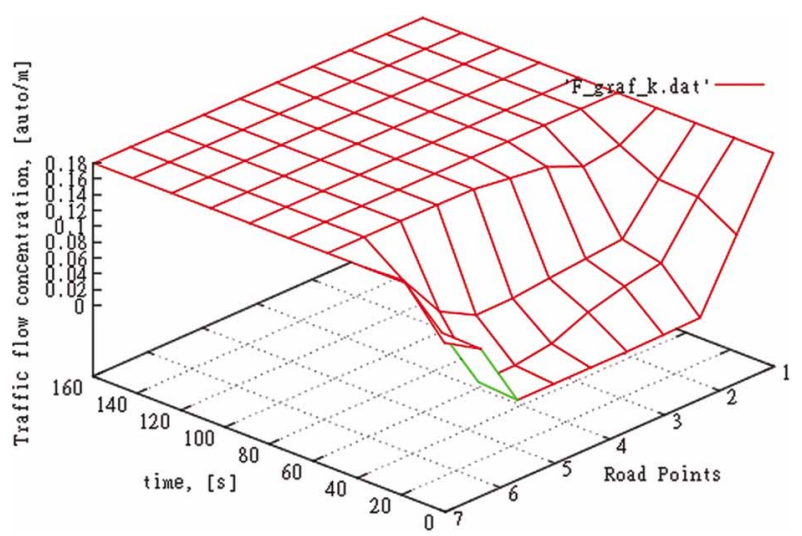

Fig. 14. Dependence of vehicles' flow concentrations on time at road points 
According to the conditions of task 2 in the beginning of modelling the road is empty, and boundary conditions are as follows: $v_{1}=1.0 \mathrm{~m} / \mathrm{s} ; v_{7}=5.0 \mathrm{~m} / \mathrm{s} ; k_{1}=$ $0.01 \mathrm{veh} / \mathrm{m} ; k_{7}=0.01 \mathrm{veh} / \mathrm{m}$ at the initial moment $k=$ $0.18 \mathrm{veh} / \mathrm{m} ; v=1.0 \mathrm{~m} / \mathrm{s}$ at all road points;

Modelling results are presented in Figs 15-21.

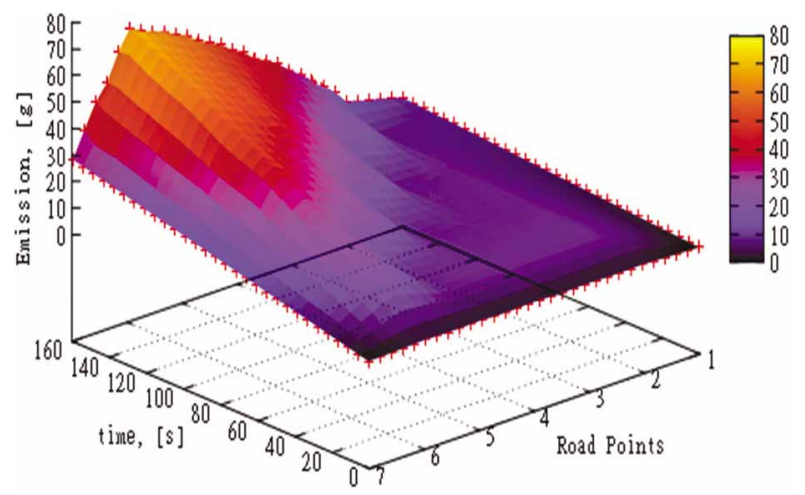

Fig. 15. Dependence of internal combustion engine $\mathrm{CO}_{2}$ emissions on time at road points

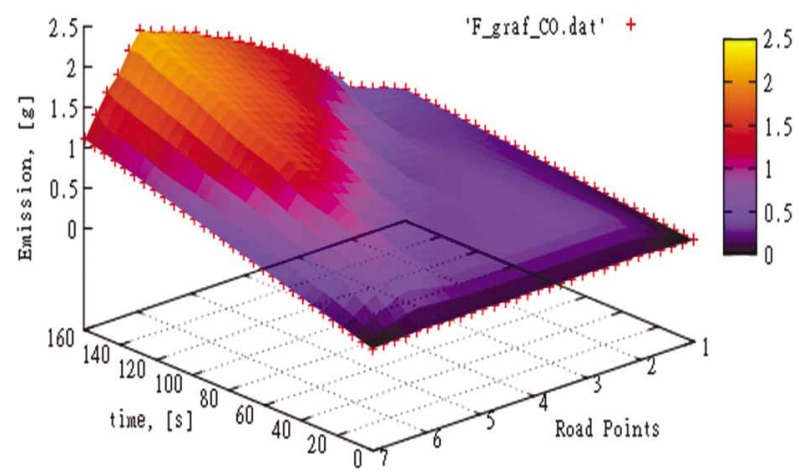

Fig. 16. Dependence of internal combustion engine $\mathrm{CO}$ emission on time at road points

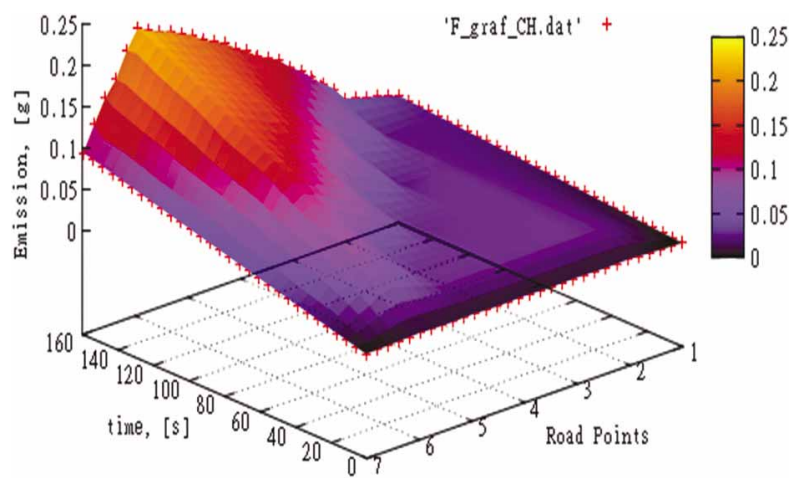

Fig. 17. Dependence of internal combustion engine $\mathrm{CH}$ emission on time at road points

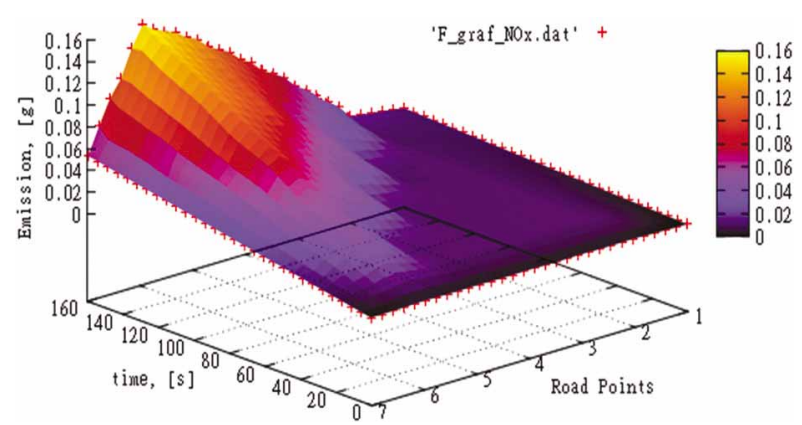

Fig. 18. Dependence of internal combustion engine $\mathrm{NO}_{\mathrm{x}}$ emission on time at road points

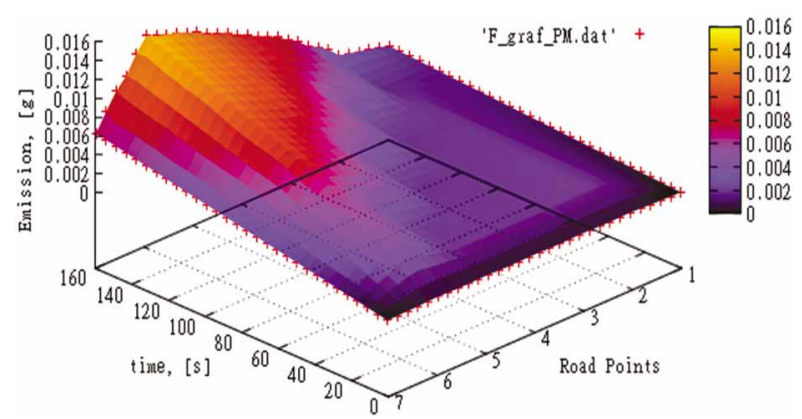

Fig. 19. Dependence of internal combustion engine Pm emission on time at road points

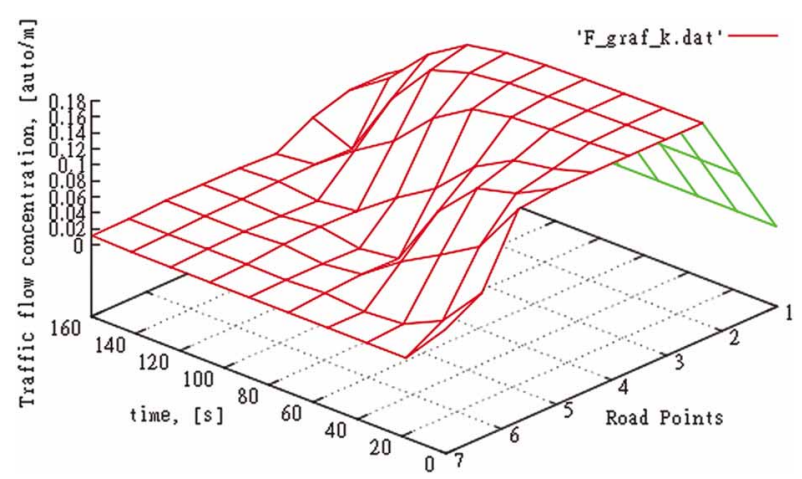

Fig. 20. Dependence of vehicles' flow concentration on time at road points

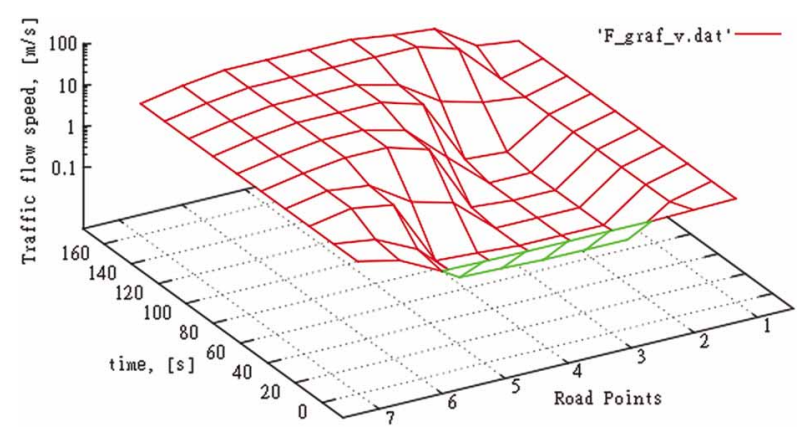

Fig. 21. Dependence of vehicles' flow speed on time at road points 


\section{Conclusions and Discussion of Simulation Results}

Two different cases are simulated.

In the first case, the road segment is empty and during simulation is filled with vehicles.

In the second case, in the beginning of simulation the road segment is filled and becomes empty during simulation. The change of traffic flow parameters $\mathrm{k}$ and $\mathrm{v}$ at all road points is shown in detail in Figs 13-14 and Figs $20-21$.

In the first case, when the road is empty, the speed at road points increases up to the maximum speed limit, and when the road is filled, it decreases to $0 \mathrm{~m} / \mathrm{s}$ Figs 13-14.

In the second case, concentration at the road points gradually starts to decrease, and the speed gradually increases up to the maximum speed limit from the last road point, Figs 20-21.

ICE emissions at all road points increase because the road segment has some vehicles. In the first case, when in the beginning of modelling the number of vehicles were almost equal to 0 , ICE emissions increase during the whole modelling time. In the beginning of modelling this increase is non-linear, and when the road segment is filled, it is linear as speed does not impact on the modelling results, Figs 8-12.

In the second case, when the road segment in the beginning of modelling is filled, ICE emissions increase as well. At the end points of the road, where vehicles start exiting, emissions start decreasing, Figs 15-19. It can be explained by the fact that at the end of the road the number of vehicles decreases and vehicles' speed increases.

\section{Acknowledgements}

The contribution of anonymous reviewers are gratefully acknowledged. This work is connected to the scientific program of the 'Development of Qualityoriented and Harmonized R+D+I Strategy and Functional Model at BME' project. These projects are supported by the New Szechenyi Development Plan (Project ID: TÁMOP-4.2.1/B-09/1/KMR-2010-0002) and 'Modelling and multi-objective optimization based control of road traffic flow considering social and economical aspects' program CNK 78168 of OTKA. The authors are grateful for the support of Bólyai János Research fellowship of HAS (Hungarian Academy of Scinence).

\section{References}

Descombes, G.; Maroteaux, F.; Feidt, M. 2003. Study of the interaction between mechanical energy and heat exchanges applied to IC engines, Applied Thermal Engineering 23(16): 2061-2078. doi:10.1016/S1359-4311(03)00160-1

Jakimavičius, M.; Burinskienė, M. 2009a. A GIS and multi-criteria-based analysis and ranking of transportation zones of Vilnius city, Technological and Economic Development of Economy 15(1): 39-48. doi:10.3846/1392-8619.2009.15.39-48

Jakimavičius, M.; Burinskiené, M. 2009b. Assessment of Vilnius city development scenarios based on transport system modelling and multicriteria analysis, Journal of Civil Engineering and Management 15(4): 361-368. doi:10.3846/1392-3730.2009.15.361-368
Jakimavičius, M.; Burinskienè, M. 2010. Route planning methodology of an advanced traveller information system in Vilnius city, Transport 25(2): 171-177. doi:10.3846/transport.2010.21

Janulevičius, A.; Juostas, A.; Pupinis, G. 2010. Engine working modes during tractors operational period, Mechanika (3): 58-63.

Jović, J.; Đorić, V. 2010. Traffic and environmental street network modelling: Belgrade case study, Transport 25(2): 155-162. doi:10.3846/transport.2010.19

Junevičius, R.; Bogdevičius, M. 2009. Mathematical modelling of network traffic flow, Transport 24(4): 333-338. doi:10.3846/1648-4142.2009.24.333-338

Kliukas, R.; Jaras, A.; Kačianauskas, R. 2008. Investigation of the traffic-induced vibration in Vilnius Arch-Cathedral belfry, Transport 23(4): 323-329. doi:10.3846/1648-4142.2008.23.323-329

Lietuvoje iregistruotu keliu transporto priemoniu skaičiai (2011 m. sausio 1 d. duomenys). 2011. Quantity of registered road vehicles in Lithuania (1 January 2011). Available from Internet: <http://www.regitra.lt/uploads/documents/dokumentai/2011\%2001\%2001\%20Registruot\%C5\%B3\%20 TP\%20kiekis\%20savivaldyb\%C4\%97se.pdf> (in Lithuanian).

Makaras, R.; Sapragonas, J.; Keršys, A.; Pukalskas, S. 2011. Dynamic model of a vehicle moving in the urban area, Transport 26(1): 35-42. doi:10.3846/16484142.2011.558630

Mansha, M.; Saleemi, A. R.; Ghauri, B. M. 2010. Kinetic models of natural gas combustion in an internal combustion engine, Journal of Natural Gas Chemistry 19(1): 6-14. doi:10.1016/S1003-9953(09)60024-4

Markovits-Somogyi, R.; Torok, A. 2010. Statistical analysis of the Hungarian vehicle fleet with special emphasis on emissions, in 11th IAEE European Conference: Proceedings, 25-28 August 2010, Vilnius, Lithuania, 275-284.

Sivilevičius, H. 2011. Modelling the interaction of transport system elements, Transport 26(1): 20-34. doi: $10.3846 / 16484142.2011 .560366$

Smit, R.; Brown, A. L.; Chan, Y. C. 2008. Do air pollution emissions and fuel consumption models for roadways include the effects of congestion in the roadway traffic flow?, Environmental Modelling and Software 23(10-11): 1262-1270. doi:10.1016/j.envsoft.2008.03.001

Tanczos, K.; Torok, A. 2007. The linkage between climate change and energy consumption of Hungary in the road transportation sector, Transport 22(2): 134-138.

ÚTMUTATÓ a külterületi közúthálózati fejlesztések költséghaszon vizsgálatához II. külső hatások Gazdasági és Közlekedési Minisztérium Hálózati Infrastruktúra Főosztály. 2006. [Guide the suburban road network development costbenefit test. Vol. II. External influences. 2006. Ministry of Economy and Transport Network Infrastructure Department]. 23 p. (in Hungarian).

Wang, H.; Fu, L.; Zhou, Y.; Li, H. 2008. Modelling of the fuel consumption for passenger cars regarding driving characteristics, Transportation Research Part D: Transport and Environment 13(7): 479-482. doi:10.1016/j.trd.2008.09.002

Wu, J.-D.; Liu, J.-C. 2011. Development of a predictive system for car fuel consumption using an artificial neural network, Expert Systems with Applications 38(5): 4967-4971. doi:10.1016/j.eswa.2010.09.155

Žiliūtè, L.; Laurinavičius, A.; Vaitkus, A. 2010. Investigation into traffic flows on high intensity streets of Vilnius city, Transport 25(3): 244-251. doi:10.3846/transport.2010.30 